\title{
Iron and Manganese Mineralization Associated with Archean Greenstone Belt in Joda-Noamundi Sector, Odisha, East Indian Shield
}

\author{
R. Ghosh", D. Chakraborty, M. Halder, T. K. Baidya \\ Department of Geological Sciences, Jadavpur University, Kolkata-700032, India
}

Email address:

rupamkumarsp@gmail.com(R. Ghosh)

To cite this article:

R. Ghosh, D. Chakraborty, M. Halder, T. K. Baidya. Iron and Manganese Mineralization Associated with Archean Greenstone Belt in JodaNoamundi Sector, Odisha, East Indian Shield. Earth Sciences. Special issue: Archean Metallogeny and Crustal Evolution.

Vol. 4, No.4-1, 2015, pp.31-39. doi: 10.11648/j.earth.s.2015040401.13

\begin{abstract}
Iron and manganese mineralization in the Joda-Noamundi sector is associated with Banded Iron Formation of the Archean Iron Ore Group of rocks (3.5-3.0 Ga).Both Mn and Fe mineralization is stratiform and stratabound. In the Noamundi basin the estimated reserve of Fe and $\mathrm{Mn}$-ores are $3.3 \mathrm{Gt}$ and $130 \mathrm{Mt}$ respectively. The Fe and Mn-mineralization are also genetically related to each other. A detailed petrology, mineralogy and mineral chemistry of the ores show their evolution with respect to different tectonic phases. During the first phase of deformation and metamorphism Fe-protolith generated magnetite and Mn-protolth generated bixbyite, hausmannite, jacobsite and braunite. During second phase martitized magnetite and hematite in Fe-ore and hollandite, psilomelane and pyrolusite in Mn-ore were generated. During supergene events low temperature higher oxide minerals were generated from the metamorphic and hydrothermal Fe and Mn -ore minerals. The stratigraphic status of the Fe- and Mn- ores with respect to crustal evolution has been established.
\end{abstract}

Keywords: Archean, Fe-Mn-ores, Iron Ore Group, East Indian Shield

\section{Introduction}

Archean iron and manganese mineralization in greenstone belts are reported from limited occurrences viz. the Rio das velhas deposit of Brazil (Machado and Carneiro [1]; Teixeira, et al.[2]; Martin, et al.[3]), the Barberton greenstone belt of South Africa (De Wit, et al.[4]; Anhaeusser and Wilson[5]), the Yilgarn and Pilbara blocks of Western Australia (Condie[6]; Hallberg and Glickson[7]), the SebakwianBulawayan-Shamvaian belt of Zimbabwe (Myers and Kröner[8]; Windley[9]), the Superior and Slave provinces of Abitibi belt, Canada (Goodwin[10]; Dimroth, et al.[11]), the Isua Formation of Greenland (Gross[12]; Schidlowski[13],[14]), the Bababudan and Chitradurga belt of South India (Ramakrishnan, et al.[15]; Chadwick, et al.[16],[17]) and the Iron Ore Group (IOG) of the East Indian Shield (Roy[18]; Ghosh, et al.[19]).

The Joda-Noamundi sector of the Noamundi Iron Ore basin of the East Indian Shield bears significant occurrence of iron and manganese mineralization which belongs to Paleo-Mesoarchean (3.5-3.0 Ga) greenstone rocks of the Iron Ore Group (IOG). Sarkar [20] estimated the remaining Fe ore resource in the Noamundi basin is about $3.3 \mathrm{Gt}$ (at more than
60 wt.\% Fe). The total Mn-ore reserve according to Indian Bureau of Mines is about 130 Mt (25-35 wt.\%Mn) (Manganese Ore Vision 2020 and Beyond[21]).

Banerji[22], Saha[23] and Roy[24] suggested the stratigraphic sequence of the IOG rocks. In this sequence Mn -minralization is bounded in upper shale which is at the upper horizon of iron formation. Beukes, et al. [25] suggested manganiferous horizon is stratigraphically at the lower horizon of ferruginous shale and iron formation in their prescribed stratigraphic model.

In this paper, the authors have enlightened the problem regarding stratigraphy of the IOG and correlated Fe and $\mathrm{Mn}$ mineralization in the Noamundi basin genetically with mineralogy, petrography and mineral chemistry.

\section{Geologic Setting}

The Precambrian rocks of the East Indian Shield are distributed in the Chhotanagpur granulite-gneiss terrain in the north, the Singhbhum granite-greenstone terrain in the south and the Singhbhum orogenic belt in between these two terrains (Fig.1). There are three major Archean greenstone belts are present at the margins of Singhbhum granitic craton 
viz. the Jamda-Koira belt at the west, the GorumahishaniBadampahar belt at the east and the Tomka-Daitari belt at the south. According to Banerji[22] and Baidya[26] the TomkaDaitari belt is the southern extension of GorumahisaniBadampahar belt. These three greenstone belts stratigraphically belong to the IOG (Table.1). The IOG rocks overlies the Singhbhum Granite Type-A and underlies the Singhbhum Granite Type-B. The Joda-Noamundi sector belongs to central and eastern part of the Noamundi basin. Banerji[22] stratigraphically characterized iron-manganese mineralization in the Jamda-Koira belt as the Noamundi
Group of much younger age (c.1500-1100 Ma) with the following sequence (ascending order) : Lower shale (tuffaceous shale - phyllite), Banded hematite jasper, Upper shale (manganiferous shale, tuff and chert), Basic intrusion, Granitic activity. Sarkar and Saha[27] \& [28] described manganese ore bodies intimately associated with unmetamorphosed shales (occasionally tuffaceous) and chert of the Archean IOG. They also considered that manganese mineralization is confined to the topmost Upper shale Formation in a belt about $80 \mathrm{~km}$ long and $25 \mathrm{~km}$ wide.

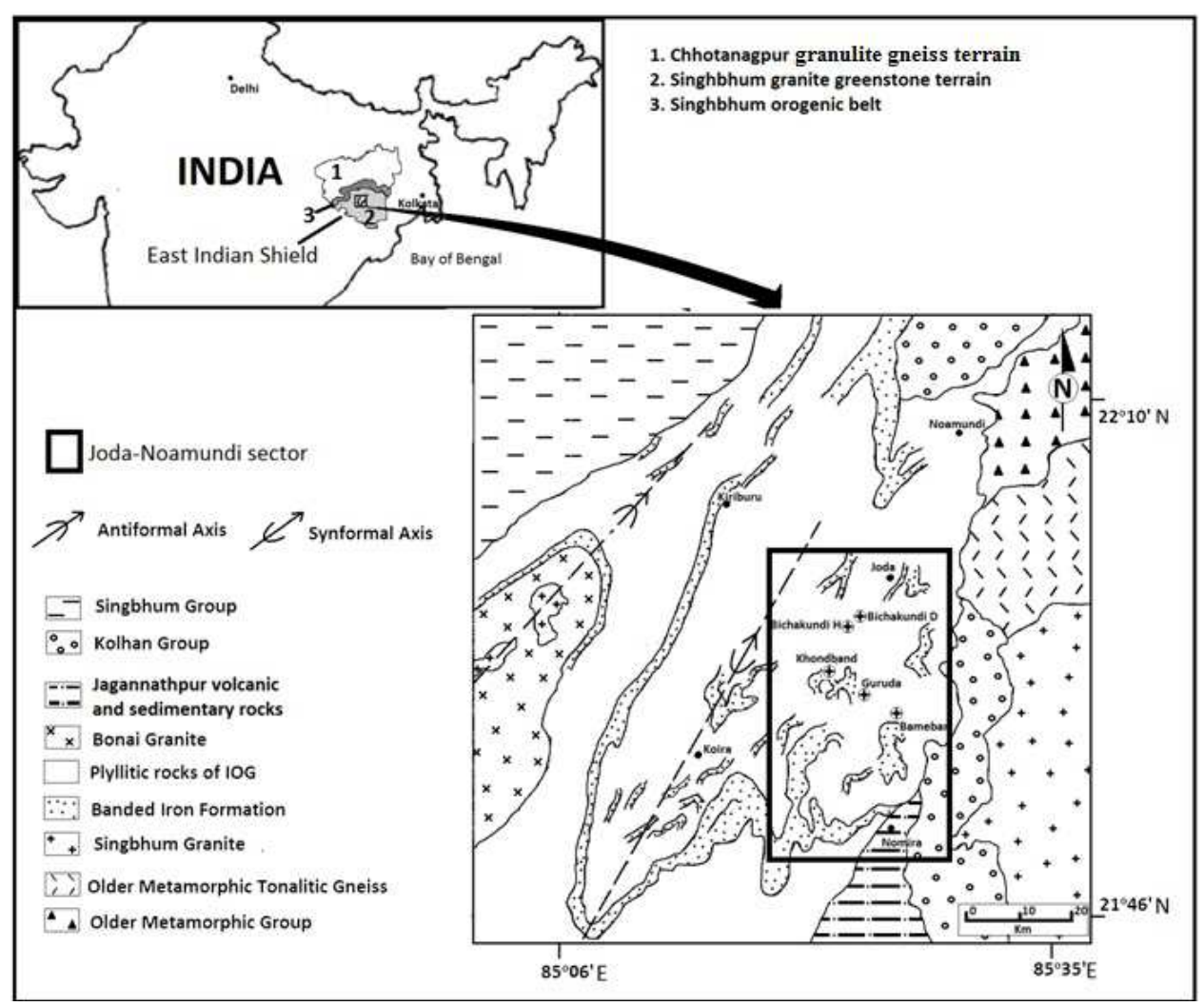

Fig.1. Geological map of the Noamundi Basin showing the Joda-Noamundi sector.

Table 1. Archean stratigraphic sequence of the Singhbhum GraniteGreenstone terrain after Saha et al.[23].

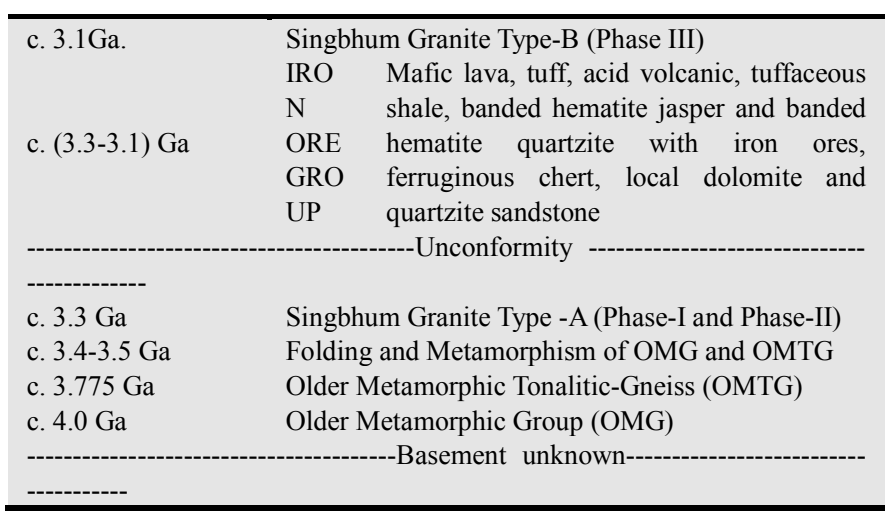

The IOG rocks occupy the major central part forming the Noamundi synclinorium. The western limb of this synclinorium is more or less continuous but characteristically devoid of any significant manganese mineralization. Iron ore is associated with BIF is present in both limbs. The eastern limb is structurally much more disturbed and dissected. It characteristically contains the major manganese ore bodies in the Joda-Noamundi sector. The corresponding anticlinal core in the western part of the Noamundi synclinorium is mainly occupied by the $3.3 \mathrm{Ga}$ Bonai granite (Saha[23]). The Older Metamorphic Group (OMG), OMTG and Singhbhum Granite occur mainly in the eastern part of the Noamundi Basin. Moorbath and Taylor [29] corrected the age of OMTG as 3.52-3.45 Ga. The Proterozoic Singhbhum group of rocks in the western part (mainly low grade metamorphosed volcanic and sedimentary rocks), the Kolhan Group (unmetamorphosed sedimentary rocks) and the JagannathpurMalangtoli volcanic rocks unconformably overlie the Singhbhum Granite Phase -III.

Due to the lack of proper geochronological data, the absolute age of the three greenstone belts of the IOG is quite uncertain. A relative age can be provided by the fact that the 
rocks of IOG overlie the Singhbhum Granite Type -A and intruded by the younger granites like Bonai granite in the west \& Mayurbhanj granite in the east. The Singhbhum Granite Type-A, the Bonai granite and the Mayurbhunj Granite have been dated as $3328 \pm 7 \mathrm{Ma}$ (single zircon $\mathrm{Pb}-\mathrm{Pb}$, Misra et. al. [30]), $3163 \pm 126 \mathrm{Ma}$ (Pb-Pb age, Sengupta et. al. [31]) and 3080 $\pm 8 \mathrm{Ma} \& 3092 \pm 5 \mathrm{Ma}$ (single zircon $\mathrm{Pb}-\mathrm{Pb}$, Misra et. al. [30]) respectively. Mukhopadhyay et. al. [32] reported $3.51 \mathrm{Ga}$ dacitic volcanics from the Tomka-Daitari belt of the IOG.

\section{Geology of the Mineralized Areas}

The iron and manganese ore bodies of the Noamundi basin is stratiform and stratabound in character. The Manganese ore bodies occur as lenticular bands hosted mainly by phyllitic rocks. The phyllitic rocks are very light colored and thinly banded resembling laminated shale. The host rock is composed of mainly very fine grained phyllosilicate minerals and minor ore minerals. These are actually metamorphosed tuffaceous materials (Ghosh et. al. [19]). The Mn-ores are mainly of four types: massive, banded, brecciated and colloform (pisolitic/ botryoidal/ reniform) (Fig.2A). The iron ore bodies are mainly hosted bybanded jasper quartzite.Iron ore bodies contain massive, banded, friable and colloform type ores (Fig.2B, 2C).

The local sequence encountered in the quarry sections (bottom to top) is banded jasper quartzite, manganese ore bodies hosted by phyllites, ferruginous phyllites and banded hematite jasper with iron ores (Fig.2D, 2E). The banded jasper quartzite bodies are made of centimetre thick alternate layers of jasper -rich and quartz -rich bands (Fig.2F). The overlying manganiferous phyllite (purple to cream colored) mainly hosts the Mn-ore bodies (Fig.2G). Although colloforms of secondary iron ore minerals viz. goethite, hematite etc. are also found along with Mn-ores. The ferruginous phyllite (red to yellow colored) at the upper horizon of manganiferous phyllite hosts patchy supergene hematite and goethite rich iron ores (Fig.2D,2E). The banded hematite ores hosted by BIF are at the uppermost level of the quarries (Fig.2C).
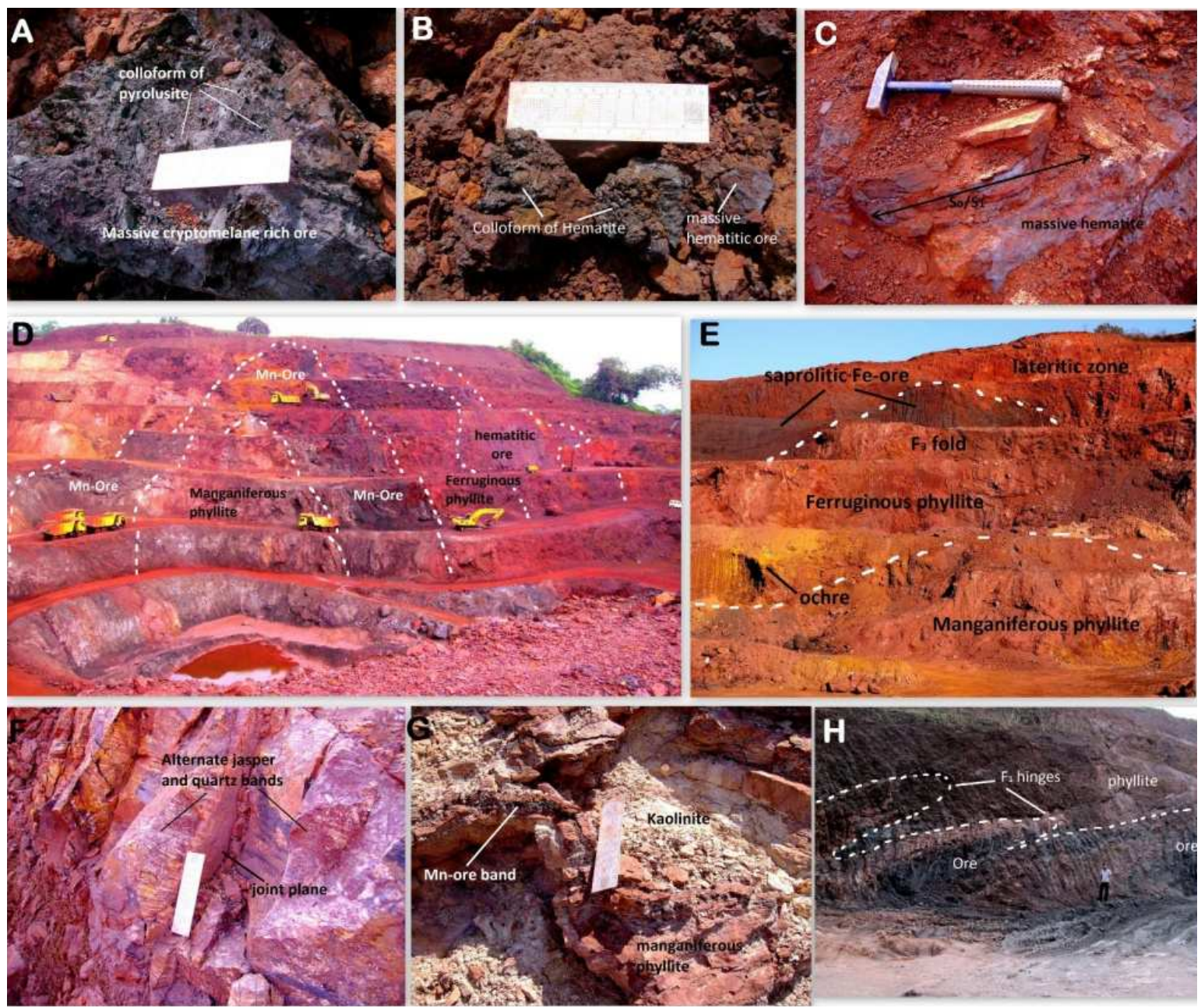

Fig. 2. Field photographs showing lithological characteristics in the mineralized zones in Joda-Noamundi sector, Noamundi Basin, East Indian Shield. A. Massive cryptomelane ore with pyrolusite colloform. B. massive and colloform hematite ore. C. Massive hematite ore is assosiated with iron BIF. D. Quarry section shows folded lithologic units of manganiferous phyllite, ferruginous phyllite and hematitic ores. E. lithologic units of manganiferous phyllite andsaprolitic Fe-ore within ferruginous phyllite. F. Banded jasper quartzite at the basement of a quarry. G. Folded Mn-ore band within manganiferous phyllite. H. Recumbent folds of Mn-ores and phyllite in a Mn-ore zone. (length of scale $: 16 \mathrm{~cm}$, length of hammer : $50 \mathrm{~cm}$, height of quarry bench : 15ft appx.) 
During the structural study, the authors found four deformational phases. The earliest deformational phase $\left(\mathrm{D}_{1}\right)$ produced regional NNE plunging isoclinal fold $\left(\mathrm{F}_{1}\right)$ which has overturned eastern limb. The axial plane schistosity $\left(\mathrm{S}_{1}\right)$ mostly corresponds to compositional banding (So) of rock in Joda-Noamundi sector. Because of the overturned folding the lithological sequence encountered at the quarry sections inthe eastern part of Noamundi basin is stratigraphically reverse. The actual chronostratigraphic sequence should be (ascending order) banded hematite jasper with iron ores, ferruginous phyllites, manganese ore bodies hosted by phyllites and banded jasper quartzite. This stratigraphic sequence is also supported by the works of Banerji[22] and Saha[23].Some recumbent $F_{1}$ folds were also generated during $\mathrm{D}_{1}$ stage (Fig.2H).The second deformational phase $\left(D_{2}\right)$ caused NNE and SW plunging tight to isoclinal $F_{2}$ fold. The third phase of tectonic deformation $\left(\mathrm{D}_{3}\right)$ produced WNW plunging mainly open type $F_{3}$ fold. The $F_{2}$ and $F_{3}$ interference caused dome and basin structure. Subsequent to third deformational phase the rocks were subjected to faulting and shearing $\left(\mathrm{D}_{4}\right)$.
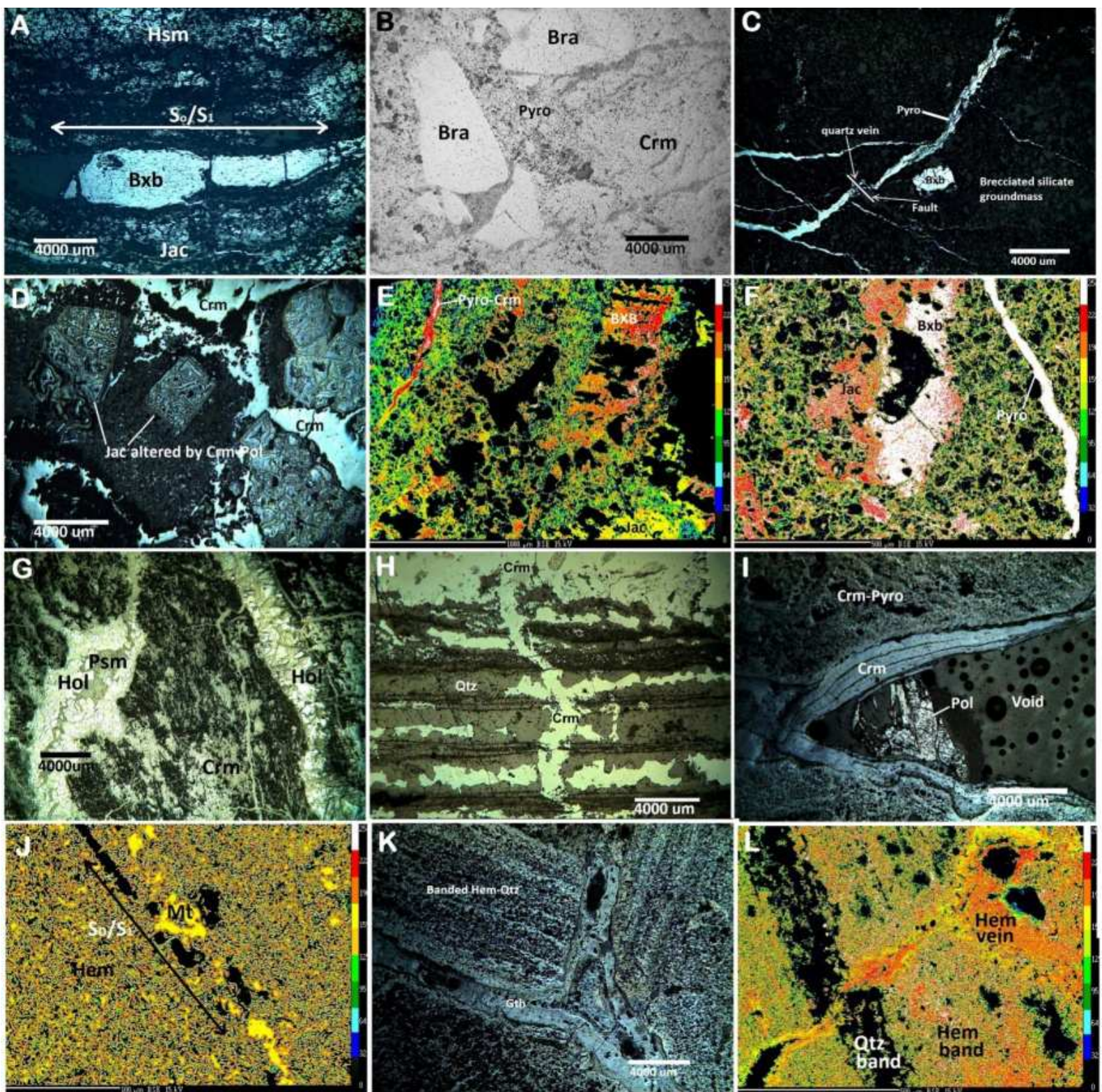

Fig. 3. Photomicrographs of Mn- and Fe-ores. A. Banded bixbyite (Bxb), hausmannite (Hsm), jacobsite (Jac) with phyllosilicates is boudinized. B. Brecciated clasts of braunite (Bra) within cryptomelane (Crm) and pyrolusite (Pyro) groundmass. C. Bixbyite (Bxb) porphyroblast is present within brecciated silicates. Supergene pyrolusite (Pyro) vein is intruded by later quartz vein. D. Jacobsite (Jac) is altered by cryptomelane (Crm) and polianite(Pol). E. False color image (FCI) shows brecciated Bxb porpyroblasts and silicates in Pyro and silicate rich groundmass. F. Bxb and Jac porpyroblasts in brecciated groundmass. G. Hydrothermal hollandite(Hol) and psilomelane (Psm) veins intrude early ore assemblages. H. Supergene Crm is present along and across banded quartzite. I. Crm and polianite (Pol) are present as void filling colloform at the interstitial space of Crm-Pyro clasts. J. rim of hematite (Hem) over magnetite (Mt) is present as a band alternating with disorientated acicular Hem rich band. K. Void fill of goethite (Gth) at the interstitial space of brecciated banded hematite quartzite clasts. L. Void fill of Hem is present in banded hematite-quartzite. 


\section{Mineralogy and Petrography of Fe- Mn-Ores}

The major Mn-mineral phases in the ore deposit are pyrolusite, cryptomelane, polianite and groutite.The earlier workers i.e. Banerji[22]; Roy [18]; Mohapatra et al.[33]; Mishra et al.[34] reported mainly low temperature minerals in the ores of the present area e.g. pyrolusite, psilomelane, manganite,rhodochrosite, cryptomelane, lithiophorite, chalcophanite, goethite,todorokite, and braunite and they considered that these minerals were formed in near-surface conditions under relatively high oxidizing environment. Ghosh et al. [19] reported 15 new manganese minerals from this deposit. They also stated that formation of bixbyite, braunite, jacobsite and hausmannite is related to first stage of deformation and metamorphism $\left(\mathrm{D}_{1} / \mathrm{M}_{1}\right)$, hollandite, psilomelane and pyrolusite is related to second stage of deformation and metamorphism $\left(\mathrm{D}_{2} / \mathrm{M}_{2}\right)$ and pyrolusite, cryptomelane, groutite, polianite etc. is related to supergene events.

The compositionally banded character of Mn-ore is observed during petrography. Hausmannite, bixbyite and jacobsite -rich bands occur alternatingly with phyllosilicate rich band where Mn-mineral rich more competent bands are boudinized (Fig.3A). Brecciated fragments of braunite is found in pyrolusite, cryptomelane and silicate rich groundmass (Fig.3B). Discrete grains of bixbyite and jacobsite are present in pyrolusite-cryptomelane and brecciated silicate mineral-rich groundmass (Fig.3C,3D,3E,3F). Bixbyite grains are highly altered to pyrolusite, cryptomelane etc. where cryptomelane and polianite have replaced jacobsitegrains.Pyrolusite has formed after braunite at the boundaries. Hydrothermal veins of hollandite and psilomelane are also ubiquitous (3G). Supergene cryptomelane and pyrolusite veins are common along weak planes $(3 \mathrm{H})$. Cavity filling of cryptomelane and polianite during supergene event is also observed (3I).

The major Fe-mineral phases in the iron ore bodies are hematite and goethite. Although Beukes et al.[25] and Upadhyay et al. [35] reported martite, limonite etc. minerals from Noamundi basin Fe-ore deposit.

Alternate bands of anhedral to subhedral martitized magnetite and acicular hematite is found in massive Fe-ore. Magnetite relicts are present inside hematite rim of higher reflectance. Acicular hematite crystals are 5-10 $\mu \mathrm{m}$ long and haphazardly oriented (Fig.3J).During D2/M2 stage major hydrothermal activity might have generated hematite in expense of magnetite. In brecciated Fe-ore goethite colloform is found at the interstitial space of the brecciated

Table 2. Generalised mineral composition of the major minerals in manganese and iron ores of Joda-Noamundi sector, Noamundi Basin, East Indian Shield.

\begin{tabular}{|c|c|c|c|c|c|c|c|c|c|c|c|c|c|}
\hline \multirow[t]{2}{*}{ Points } & Bxb & Jac & Hsm & Hol & Psm & Pyro,H & Pyro,S & $\begin{array}{l}\text { Mgm, } \\
\text { S }\end{array}$ & $\begin{array}{l}\text { Gth- } \\
\text { Grt- } \\
\text { Dsp }\end{array}$ & Hem & Dsp & Mart & Gth \\
\hline & $n=15$ & $n=5$ & $\mathrm{n}=2$ & $n=3$ & $n=5$ & $n=5$ & $\mathrm{n}=9$ & $n=10$ & $n=6$ & $n=12$ & $\mathrm{n}=2$ & $\mathrm{n}=7$ & $n=5$ \\
\hline $\mathrm{Na}_{2} \mathrm{O}$ & 0.21 & 0.17 & 0.10 & 0.21 & 0.15 & 0.09 & 0.15 & 0.71 & 0.09 & 0.14 & 0.40 & 0.20 & 0.35 \\
\hline $\mathrm{MgO}$ & 0.09 & 0.23 & 0.14 & 0.40 & 0.36 & 0.15 & 0.22 & 0.17 & 0.40 & 0.50 & 0.69 & 0.55 & 0.69 \\
\hline $\mathrm{SiO}_{2}$ & 0.40 & 3.86 & 0.49 & 0.36 & 0.18 & 0.60 & 0.26 & 0.36 & 3.75 & 0.06 & 0.10 & 0.14 & 0.08 \\
\hline $\mathrm{Al}_{2} \mathrm{O}_{3}$ & 3.38 & 7.17 & 0.73 & 1.28 & 0.67 & 0.42 & 1.35 & 0.64 & 10.71 & 1.05 & 97.06 & 0.88 & 1.28 \\
\hline $\mathrm{P}_{2} \mathrm{O}_{5}$ & - & - & - & - & - & 0.84 & 0.22 & 1.40 & - & 0.06 & 0.04 & 0.02 & - \\
\hline $\mathrm{K}_{2} \mathrm{O}$ & 1.47 & 0.65 & 0.23 & 1.08 & 1.53 & 2.90 & 1.90 & 3.43 & 0.50 & 0.01 & 0.02 & 0.12 & 0.03 \\
\hline $\mathrm{CaO}$ & 0.32 & 0.24 & 0.27 & 0.90 & 1.02 & 0.40 & 0.42 & 0.11 & 0.17 & 0.14 & 0.10 & 0.11 & 0.22 \\
\hline $\mathrm{TiO}_{2}$ & 0.02 & 0.38 & - & - & - & - & 0.04 & 0.03 & 0.11 & 0.01 & 0.01 & 0.04 & - \\
\hline $\mathrm{Cr}_{2} \mathrm{O}_{3}$ & 0.01 & 0.04 & 0.08 & - & 0.03 & 0.03 & 0.11 & 0.14 & 0.09 & 0.04 & - & 0.02 & 0.38 \\
\hline $\mathrm{MnO}$ & 91.33 & 51.31 & 96.37 & 82.31 & 82.79 & 88.93 & 93.27 & 85.91 & 32.19 & 0.03 & 0.12 & 0.06 & 0.70 \\
\hline $\mathrm{FeO}$ & 2.40 & 35.58 & 1.24 & 1.39 & 0.14 & 2.10 & 0.98 & 2.68 & 38.74 & 97.82 & 1.43 & 98.04 & 96.13 \\
\hline $\mathrm{CoO}$ & 0.03 & - & 0.03 & 0.36 & 0.32 & 0.30 & 0.20 & 0.17 & 0.05 & - & - & - & - \\
\hline $\mathrm{NiO}$ & 0.03 & 0.04 & 0.10 & 0.07 & 0.07 & 0.22 & 0.12 & 0.37 & 0.71 & - & 0.01 & 0.02 & 0.01 \\
\hline $\mathrm{CuO}$ & 0.04 & 0.02 & 0.18 & 0.21 & 0.22 & 0.33 & 0.03 & 0.13 & 0.03 & - & - & - & - \\
\hline $\mathrm{ZnO}$ & 0.06 & 0.12 & - & 0.05 & 0.07 & 0.66 & 0.01 & 0.60 & 0.08 & - & - & - & - \\
\hline $\mathrm{BaO}$ & 0.04 & 0.04 & 0.01 & 11.34 & 9.33 & 0.89 & 0.34 & 1.05 & 0.13 & 0.04 & - & 0.02 & 0.02 \\
\hline $\mathrm{ZrO}_{2}$ & 0.14 & 0.12 & 0.16 & 0.08 & 0.03 & - & 0.03 & - & 0.06 & 0.09 & - & 0.03 & 0.13 \\
\hline $\mathrm{V}_{2} \mathrm{O}_{3}$ & 0.03 & 0.02 & - & 0.03 & 0.03 & 0.15 & 0.02 & 0.22 & 0.05 & 0.01 & 0.02 & 0.01 & - \\
\hline $\mathrm{PbO}$ & - & - & - & - & - & 0.57 & 0.13 & 0.97 & - & - & - & - & - \\
\hline $\mathrm{As}_{2} \mathrm{O}_{3}$ & - & - & - & - & - & - & - & 0.28 & - & - & - & - & - \\
\hline S & - & - & - & - & - & 0.15 & 0.02 & 0.18 & - & - & - & - & - \\
\hline $\mathrm{Ag}$ & - & - & - & - & - & 0.08 & 0.12 & 0.21 & - & - & - & - & - \\
\hline $\mathrm{Au}$ & - & - & - & - & - & 0.17 & 0.04 & 0.24 & - & - & - & - & - \\
\hline Total & 99.99 & 100.00 & 100.00 & 100.05 & 96.94 & 100.01 & 100.00 & 100.00 & 87.84 & 100.00 & 100.00 & 100.01 & 100.00 \\
\hline
\end{tabular}


quartz ore (Fig.3L). Supergene veins of diaspore and goethite are also present.

\section{Mineral Chemistry}

In the $\mathrm{Mn}$-ore, the major $\mathrm{D}_{1} / \mathrm{M}_{1}$ minerals are bixbyite, jacobsite, hausmannite, $\mathrm{D}_{2} / \mathrm{M}_{2}$ minerals are hollandite, psilomelane and pyrolusite and supergene stage minerals are cryptomelane, pyrolusite and groutite-goethite-diaspore. Mineral chemistry of bixbyite shows they are typically Mnrich. Although some amounts of $\mathrm{Fe}$ and $\mathrm{Al}$ are present. Ghosh et al. [19] concluded that the $\mathrm{Fe}$ and $\mathrm{Al}$ in bixbyite is due to supergene alteration by goethite-diaspore. $\mathrm{K}$ percent is more than $\mathrm{Na}, \mathrm{Ca}, \mathrm{Mg}$ and $\mathrm{Ba}$. $\mathrm{Zr}$ amount is significant. Trace amounts of $\mathrm{Cu}, \mathrm{Ni}, \mathrm{Cr}, \mathrm{Co}, \mathrm{V}, \mathrm{Ti}$ and $\mathrm{Cr}$ are also present. The mineral formula of bixbyite generated from compositional data is $\left(\mathrm{Mn}_{1.88} \mathrm{Fe}_{0.04} \mathrm{Al}_{0.08}\right) \mathrm{O}_{3}$.In jacobsite $\mathrm{Fe}$ and $\mathrm{Mn}$ ratio is around 5:3. Significant amount of $\mathrm{Al}^{+3}$ is present in structure replacing $\mathrm{Fe}^{+3}$ and $\mathrm{Mn}^{+3}$ in tetrahedral site. Minor amounts of $\mathrm{Zr}, \mathrm{Na}, \mathrm{K}, \mathrm{Ca}, \mathrm{Mg}$, Ti \& $\mathrm{Zn}$ and trace amounts of $\mathrm{Ni}, \mathrm{Cu}, \mathrm{Ba} \& \mathrm{Cr}$ are also present. The calculated mineral formula of jacobsite is $\left(\mathrm{Mn}_{1.62} \mathrm{Fe}_{1.14} \mathrm{Al}_{0.24}\right) \mathrm{O}_{4}$. The available analysis data it is clear that hausmannite structure hardly allowed other elements to occupy cation sites. This fact is also supported by other workers (Frenzel [36] and Roy [18]). Although minor amounts of $\mathrm{Na}, \mathrm{Mg}, \mathrm{Si}, \mathrm{Al}, \mathrm{Ca}, \mathrm{K}, \mathrm{Ni}$, $\mathrm{Cu}$ and $\mathrm{Zr}$ are present (Table.2). The high $\mathrm{Ba}$ and minor amounts of $\mathrm{Co}, \mathrm{Ni}, \mathrm{Cu}$ and $\mathrm{Zn}$ in hollandite, psilomelane and pyrolusite is quite significant in $\mathrm{D}_{2} / \mathrm{M}_{2}$ stage. Minor amounts of $\mathrm{Na}, \mathrm{K}, \mathrm{Mg}, \mathrm{Ca}, \mathrm{Al}$ and $\mathrm{Fe}$ is also present. The calculated mineral formulae of hollandite and psilomelane are $\left(\mathrm{Ba}_{0.81} \mathrm{~K}_{0.08} \mathrm{Ca}_{0.06} \mathrm{Na}_{0.01} \mathrm{Mg}_{0.03}\right) \mathrm{Mn}_{8} \mathrm{O}_{16} \quad$ and $\left(\mathrm{Ba}_{0.75} \mathrm{~K}_{0.12} \mathrm{Ca}_{0.08} \mathrm{Mg}_{0.03} \mathrm{Na}_{0.01}, \quad \mathrm{H}_{2} \mathrm{O}\right)_{2} \mathrm{Mn}_{8} \mathrm{O}_{16} \quad \mathrm{nH}_{2} \mathrm{O}$ respectively. The supergene minerals i.e. manganomelane, pyrolusite and groutite-goethite-diaspore contains almost all major and minor elements in variable amounts. The calculated generalized chemical formula of manganomelane group of minerals is $\left(\mathrm{K}_{0.56} \mathrm{Ba}_{0.17} \mathrm{Na}_{0.11} \mathrm{~Pb}_{0.15}\right) \mathrm{Mn}_{8} \mathrm{O}_{16} \cdot \mathrm{nH}_{2} \mathrm{O}$. The diaspore group of minerals i.e. goethite, groutite and diaspore are present as solid solution withvariable proportion. The generalized formula of this solid solution calculated is $\left(\mathrm{Fe}_{0.47} \mathrm{Mn}_{0.39} \mathrm{Al}_{0.13}\right) \mathrm{O}(\mathrm{OH})$.

The major minerals present in Fe-ores are martite, hematite, diaspore and goethite. The martitized magnetite and hematite grains are essentially Fe rich. Minor amounts of $\mathrm{Na}, \mathrm{Mg}, \mathrm{Al}, \mathrm{K} \& \mathrm{Ca}$ and trace amounts of $\mathrm{Si}, \mathrm{P}, \mathrm{Ti}, \mathrm{Cr}, \mathrm{Mn}$, $\mathrm{Ba}, \mathrm{Zr} \& \mathrm{~V}$ are also present in the grains. Analysis of two diaspore in form of supergene vein shows that they are Al rich. Minor amounts of $\mathrm{Fe}, \mathrm{Na}$ and $\mathrm{Mg}$ and trace amounts of $\mathrm{Si}, \mathrm{P}, \mathrm{Ca}$ and $\mathrm{Mn}$ are also present.

\section{Discussion and Conclusion}

Paleo-Mesoarchean crustal evolution and corresponding metallogeny events took place in the three greenstone belts (belongs to the IOG) at the margins of the Singhbhum craton. The Jamda-Koira greenstone belt at the western margin contains significant iron and manganese mineralization associated with BIF and volcanic rocks. The synsedimentary iron and manganese ores were subjected to three subsequent phases of tectonic deformation. During first phase of deformation $\left(D_{1}\right)$ the region was subjected to nearly eastwest compression which ultimately formed the regional synclinorium $\left(\mathrm{F}_{1}\right)$ with NNE-trending and easterly dipping axial plane. The regional fold has overturned limb at the eastern part particularly in the Joda-Noamundi sector. That is why the lithologic sequence encountered here is actually stratigraphically reverse.

Grant et al. [37],Avasthy[38],Sarkar [39] and Raha and Moitra[40] reported algal stromatolites and spheroidal \& filamentous microfossils in the BIF and manganese ore horizon of the Noamundi basin. Beukes et al. [25] studied the Fe-ores of the Noamundi basin and concluded that the original magnetite rich Fe-ore protolith evolved to high grade hematite ore in three stages i.e. hydrothermal activity and atleast two successive supergene events.According to Moriyama, et al. [41], the post-Archean average shale normalized REE patterns of IOG iron, ferro-manganese and manganese ores of Noamundi basin show HREE enrichment, negative $\mathrm{Ce}$ anomaly and positive $\mathrm{Eu}$ anomaly which are similar to modern ferro-manganese sediments near midoceanic ridges (Barrett \& Jarvis [42]). In oxic sea water Ce is removed as $\mathrm{CeO}_{2}$ or $\mathrm{Ce}(\mathrm{OH})_{4}$ by oxidation reaction. Seawater has LREE depletion and negative Ce anomaly (Douville, et al. [43]). A positive Eu anomaly is a typical characteristic of modern manganese hydrothermal deposits in the ocean (Hodkinson, et al. [44]). Thus Moriyama, et al. [41] concluded that the sedimentary type ore body was deposited in presence of oxic oceanic water mixed with submarine hydrothermal components.

Detailed study in manganese mineralized areas by Ghosh, et al. [19] revealed two major facts. The manganese ore bodies are structurally $\left(\mathrm{D}_{2} / \mathrm{F}_{2}\right)$ controlled. The Mnmineralization took place in several phases i.e. syngenetic sedimentary/exhalative, $\mathrm{D}_{1} / \mathrm{M}_{1}$ stage (bixbyite, jacobsite, hausmannite and braunite), $\mathrm{D}_{2} / \mathrm{M}_{2}$ stage (hollandite, psilomelane and pyrolusite) and supergene stages (pyrolusite, cryptomelane, polianite, groutite, goethite). They also stated that the phyllitic host rocks were initially some alumina rich and silica poor tuffaceous material rather than some original argillaceous sedimentary rock. The presence of stromatolites, the concentrations of $\mathrm{Eu} \& \mathrm{Ce}$ in the rocks and presence of dolomite \& quartz arenite at the base of the IOG rocks in the Noamundi basin indicate oxygenated shallow platformal marine environment of deposition in the Noamundi basin.

The Fe and $\mathrm{Mn}$-mineralization of the present area may be compared to the other deposits in the world viz. the Isua Complex of Greenland and the Warrawoona group of Western Australia because of their similarity of ageand association. The 3800 Ma old Isua Complex of the Greenland (with earliest evidence of life) contains $\mathrm{Fe}$ and Mn-ores along with BIF associated with greenstone sequence of schists, phyllites, tuffs and basic volcanics (Schidlowski [13],[14]; Mojzsis, et al.[45]; Hayes [46]; Nutman, et al.[47]).The 3500 Ga Warrawoona 
Group of the Pilbara craton, W. Australia contains banded iron-manganese formation associated with volcaniclastic, clastic and chemical sediments (Groves, et al.[48]; Buick and Dunlop [49]).

Compositional banding of Mn-minerals and silicates shows the Mn-ores are stratiform and stratabound in character. Boudinization in these bands indicates late phase brittle deformation event. The earliest Mn minerals found as in the ore are bixbyite, jacobsite, hausmannite and braunite formed during $D_{1}$. These minerals are altered by later hydrothermal and supergene activity. The $\mathrm{Na}, \mathrm{Ca}, \mathrm{Mg}, \mathrm{K}, \mathrm{Zr}$, $\mathrm{Cr}$ and $\mathrm{Ti}$ content in these minerals are originated from original $\mathrm{Mn}$-protolith but the $\mathrm{Cu}, \mathrm{Ni}, \mathrm{Zn}$ and $\mathrm{Co}$ are derived from hydrothermal activity. The hydrothermal veins of hollandite, pyrolusite and psilomelane formed during $\mathrm{D}_{2}$ contains significant amounts of $\mathrm{Ba}, \mathrm{Cu}, \mathrm{Ni}, \mathrm{Co}$ and $\mathrm{Zn}$ which are derived from any external source. The supergene Mnminerals are found in cavity filling and vein form. Their chemical characteristics of having all elements in variable amounts indicates supergene recycling of early minerals. The goethite veins found in Mn-ore have originated from ferruginous shale or Fe-ore horizons.The compositionally banded Fe-ore minerals and quartz indicates startiform and stratabound character of ores. Relicts of euhedral to subhedral martitized magnetite grains (provably generated during $\left.D_{1} / M_{1}\right)$ are the earliest mineral found in the ore. The rims of hematite over magnetite and the disoriented acicular hematite grains are generated during hydrothermal activity. Goethite, hematite and diaspore are found in supergene cavity filling and vein form.

If we consider the depositional and late depositional scenario before deformations, Fe-ore protolith along with BIF underlies ferruginous phyllite which again underlies Mnore protolith confined in manganiferous phyllite according to field and petrographic evidences. The Fe-ore does not contain significant amount of $\mathrm{Mn}$-minerals. The Fe-minerals also contains very minor amount of $\mathrm{Mn}$ in structure. The Mnore also does not contain any primary Fe-minerals although some supergene goethite veins are present. But some $D_{1} / M_{1}$ minerals viz. bixbyite and jacobsite contain considerable amount of Fe. It indicates that the original protolith of Mnore had considerable amounts of Fe during deposition.

During deposition of $\mathrm{Fe}$ by photochemical or biological oxidation $\mathrm{Mn}$ is hardly precipitated. Anbar and Holland [50] by their experimental study of showed that photoxidation precipitation of $\mathrm{Mn}^{2+}$ is hindered by the presence of $\mathrm{Fe}^{2+}$. According to Roy [24] Fe and Mn build up took place in early Archean ocean by hydrothermal leaching of rocks but $\mathrm{Fe}$ precipitated first as the solution crossed $\mathrm{Fe}^{2+} / \mathrm{Fe}^{3+}$ chemocline first.

\section{Acknowledgments}

The authors acknowledge sincere cooperation and logistic support of M/S Tata Steel Ltd. during fieldwork particularly Mr.Tarun Chakraborty, Mr. Manikant, Mr. Mithun and the present Head of the Natural Resourses Manganese Division,
Joda. SEM-EDX studies have been done in the laboratory of the Metallurgical Engineering and Material Science Department of Jadavpur University. EPM analytical studies were done in the Central Petrological Laboratory, Geological Survey of India in CHQ, Kolkata under the guidence of Dr. Sandip Nandi and Dr. Tripathi. Sincere thanks are also due to researchers Ms. Riya Mondal and Mr. Abhisek Mondal of the Dept. of Geological Sciences, Jadavpur University for constructive suggestion and discussion.

\section{References}

[1] Machado, N. and Carnerio, M., 1992, U-Pb evidence of Late Archeantectono-thermal activity in the southern Sao Francisco Shield, Brazil: Canadian Journal of Earth Sciences, v.29, p.2341-2346.

[2] Teixeira, W., Carneiro, M.A., Noce, C.M., Machado, N., Sato, K., Taylor, P.N., 1996, Pb, Sr and Nd isotope constrains on the Archean evolution of gneissic-granitoid complexes in the southern Sao Francisco craton, Brazil. Precambrian Recearch. v.78, p.151-164.

[3] Martin, H., Peucat, J.J., Sabate, P., Cunha, J.C., 1997, Crustal evolution in the Early Archean of South America: example of the Sete Voltas Massif, Bahia State, Brazil. Precambrian Research. V.82, p.35-62.

[4] De Wit, M., Hart, R., Stern, C., Barton, C.M., 1980, Metallogenesis related to seawater interaction with 3.5 b.y. oceanic crust: EOS, v.61, p.386.

[5] Anhaeusser, C.R., and Wilson, J.F., 1981, Southern Africa: the granitic-gniess greenstone shield: In D.R. Hunter (Ed.) Precambrian of the Southern Hemisphere, Elsevier, Amsterdam, p. 423-499.

[6] Condie, K.C., 1981, Archean Greenstone Belts, Amsterdam, Elsevier.

[7] Hallberg, J.A., Glikson, A.Y., 1981, Archean granitegreenstone terrains of W. Australia. In D R Hunter (Ed.), Precambrian of the southern hemisphere, Amsterdam, Elsevier, p. 33-103.

[8] Myers, J.S., and Kröner, A., 1994, Archean Tectonics: Continental Deformation-ed. By Paul L Hancock Pergamon Press, Oxford, p. 355-369.

[9] Windly, B.F., 1982, The evolving Continents: Jhon Willey \& Publication, $2^{\text {nd }}$ ed., p. 28-65.

[10] Goodwin, A.M., 1973, Archean Iron-Formation and Tectonic Basins of the Canadian Shield: Economic geology, v.68, p.915-933.

[11] Dimroth, E., Imrch, L., Rocheleau, M., Goulet, N., 1982, Evolution of the south-central of the Archean Abitibi belt, Quebe. Part I: stratigraphy and paleogeographic model: Canadian Journal of Earth Sciences., v.19, p.1729-1758.

[12] Gross, G.A., 1986, Themetallogenetic significance of IronFormation and related stratafer rocks: Journal of Geological Society of India, v.28, p.92-108.

[13] Schidlowski, M., 1988, A 3800-million-year isotopic record of life from carbon in sedimentary rocks: Nature, v.333, p.313318. 
[14] Schidlowski, M., 1993, The beginning of life on Earth: evidence from the geological record: Greenburg, J.M. et al. eds., The chemistry of Life's Origins. Kulwar, Dordrecht, p.389-414.

[15] Ramakrishnan, M., Viswanatha, M.N., Swami Nath, J., 1976, Basement-cover relationships of Peninsular Gneiss with High Grade Schists and Greenstone Belts of southern Karnataka: Journal of Geological Society of India, v.17, p.97-111

[16] Chadwick, B., Ramakrishnan, M., Viswanatha, M.N., 1981a, Structural and metamorphic relations between Sargur and Dharwarsupracrustal rocks and Peninsular Gneiss in central Karnataka: Journal of Geological Society of India, v.22, p.557-569.1981b, The stratigraphy and structure of the Chitradurga region: an illustration of cover-basement interaction in the late Archaean evolution of the Karnataka craton, southern India. Precambrian Research: v.16, p.31-54.

[17] Roy, S., 1981, Manganese Deposits: London, Academic press.

[18] Ghosh R., Chakraborty D., Halder. M., BaidyaT.K., 2015, Manganese mineralization in Archean greenstone belt, JodaNoamundi sector, Noamundi basin, East Indian Shield. Ore Geology Reviews, Vol.70, 96-109

[19] Sarkar, S. C., 2000, Crustal evolution and metallogeny in the East Indian Craton: Geological Survey of India Special Publication 55, p.169-194.

[20] Manganese Ore vision 2020 and Beyond: Indian Bureau of Mines, Ministry of Mines, Govt. of India. Jan, 2014.

[21] Banerji, A.K. 1977, On the Precambrian banded ironformations and the manganese ores of the singhbhum region, Eastern India: Economic Geology., v.72:1, p. 90-98.

[22] Saha, A.K., 1994, Crustal Evolution of Singbhum-North Orissa, Eastern India: Geological Society of India, Bangalore, Memoir-27.

[23] Roy, S., 2000, Late Archean initiation of manganese metallogenesis: its significance and environmental controls, Ore Geology Reviews, 17, 179-198.

[24] Beukes, N.J., Mukhopadhyay, J., Gutzmer, J., 2008, Genesis of High-Grade Iron Ores of the Archean Iron Ore Group around Noamundi, India: Economic Geology, v.103, p.365-386.

[25] Baidya, T.K., 1996, Prospect of gold in some areas of Eastern Indian Shield: National Workshop on "Exploration and exploitation of gold resources of India", NGRI Hyderabad, p. 165-169.

[26] Sarkar, S.N., Saha, A.K., 1962, A revision of Precambrian stratigraphy and tectonics of Shingbhum and adjacent regions: Quaternary Journal of the Geological Mining Metallurgical Society of India, v.34, p.97-136.

[27] Sarkar, S.N., Saha, A.K. 1977, The present state of Precambrian stratigraphy, tectonics and geochronology of Singbhum-Keonjhar-Mayurbhanj region, Eastern India: Indian Journal of Earth Sciences, Calcutta. 'S Roy volume', M. K. Bose ed., p. 37-66.

[28] Moorbath, S., Taylor, P.N., 1988, Early Precambrian crustal evolution in eastern India: the age of Sinhgbhum Granite and included remnants of older gneiss (Abs.): Journal of Geological Society of India, v.31(1), p.82-84.

[29] Misra, S., Deomurari, M.P., Wiedenbeck, M., Goswami, N.J., Ray, S., Saha, A.K., 1999, 207Pb/206Pb zircon ages and the evolution of the Singhbhumcraton, eastern India: An ion microprobe study: Precambrian Research, v.93, p.139-151.

[30] Sengupta, S., Paul, D.K., de Laeter, J.R., McNaughton, N.J., Bandyopadhyay, P.K., and de Smeth, J.B., 1991, Mid-Archean evolution of the eastern indiancraton: Geochemical and isotopic evidence from the Bonai pluton: Precambrian Research, v.49, p.23-37.

[31] Mukhopadhyay, J., Beukes, N.J., Armstrong, R.A., Zimmermann, U., Ghosh, G., Medda, R.A., 2008, Dating the oldest greenstone in India: A $3.51 \mathrm{Ga}$ Precise U-Pb SHRIMP Zircon Age for Dacitic Lava of the Southern Iron Ore Group, Singhbhumcraton: Journal of geology, v.116, p.449-461.

[32] Mohapatra, B.K., Misra, P.P., Sing, P.P., Rajeev, 2002, Nature of development of lateroid type manganese ore bodies in the Iron Ore Group of rocks, Bonai-Keonjhar belt, Orissa: Indian journal of Geology, p. 145-161

[33] Mishra, P., Mohapatra, B.K., Singh, P.P., 2006, Mode of occurrence and characteristics of Mn-ore bodies in Iron Ore Group of rocks, North Orissa, India and its significance in resource evaluation: Resource Geology, v.56, p.55-64.

[34] Upadhyay, R. K., Venkatesh, A.S., Roy, S., 2010, Mineralogical Characteristics of Iron Ores in Joda and Khondbond Areas in Eastern India with Implications on Beneficiation, Resource Geology, 60, 203-211.

[35] Frenzel, G., 1980, The manganese ore minerals, Geology and geochemistry of manganese ores: I.M. Varentoov and Gy. Grasselly eds. Schweizerbart'scheVerlagsbuchhandlung, Stuttgart, p.25-290.

[36] Grant, P.R., Mury, V.N., Sengupta, S., 1980, The first record of stromatolites from Koira Group (Iron Ore Series). Precambrian of Bihar-Orissa, India: Geological Survey of India Miscellaneous Publication. V.44, p.49-53.

[37] Avasthy, R.K., 1980, Stromatolite in Iron Ore Formation of Bonai-Keonjhar district, Orissa, India: Geological Survey of India Miscellaneous Publication, v.44, p.54-56.

[38] Sarkar, B., 1984, Microfossils in Banded iron formation from the Noamundi Basin, Eastern India. Quaternary Journal of the Geological Mining and Metallurgical Society of India, v.56, p.41-46.

[39] Raha, P.K. and Moitra, A.K., 1992, The first record of stromatolites in banded hematite quartzites (sensuostricto) in the Iron Ore Group of Keonjhar District, Orissa, India-a significant step towards understanding of the depositional environment of the iron ores. $29^{\text {th }}$ International Geological Congress, abstract 1-3-47, p-12, 6544.

[40] Moriyama, T., Panigrahi, M.K., Pandit, D., Watanabe, Y., 2008, Rare Earth Element Enrichment in Late Archean Manganese Deposits from the Iron Ore Group, East India: Resource Geology, v.58, p.402-413.

[41] Barrett, T.J. and Jarvis, I., 1988, Rare-earth element geochemistry of the metalliferous sediments from DSDP Leg 92: The East Pacific Rise Transect: Chemical Geology, v.67, p.243-259.

[42] Douville, E., Bienvenu, P., Charlou, J.L., Donval, J.P., Fouquet, Y., Appriou, P., Gamo, T., 1999, Yttrium and rare earth elements in fluids from various deep-sea hydrothermal systems: GeochimicaCosmochimicaActa, v.63, p.627-643. 
[43] Hodkinson, R.A., Stoffers, P., Scholten, J., Cronan, D.S., Jeschke, G., Rogers, T.D.S., 1994, Geochemistry of hydrothermal manganese deposits from the Pitcairn Island hotspot, southeastern Pacific: GeochimicaCosmochimicaActa, v.58, p.5011-5029.

[44] Mojzsis, S.J., Arrhenius, G., McKeegan, K.D., Harrison, T.H., Nutman, A.P., Friend, C.R.L., 1996, Evidence for life on Earth before 3,800 million years ago: Nature, v.384, p.55-59.

[45] Hayes, J.M., 1996, The earliest memories of life on Earth: Nature, v. 384, p.21-22.

[46] Nutman, A.P., Mojzsis, S.J., Friend, C.R.L., 1997,
Recognition of $>3850$ Ma water-lain sediments inWest Greenland and their significance for the early Archean Earth: GeochimicaCosmochimicaActa, v.61, p.2475-2484.

[47] Groves, D.I., Dunlop, J.S.R., Buick, R., 1981, An early habitat of life: Scientific American, v.245, p.64-73.

[48] Buick, R. and Dunlop, J.S.R., 1990, Evaporitic sediments of Early Archean age from the Warrawoona Group, North Pole, Western Australia: Sedimentology, v.37, p.247-277.

[49] Anbar, A.D., Holland, H.D., 1992, The photochemistry of manganese and the origin of banded iron formation. GeochemicaCosmochemicaActa 56, 2595-2603 